\title{
Evolution of incidence, mortality and cost of non- traumatic abdominal emergencies treated in Brasil in a period of nine years
}

Carolina Maria Lemos ${ }^{1}$

Mariana Alem ${ }^{\mathbf{1}}$

Tercio de Campos ${ }^{1}$

1. Universidade Anhembi Morumbi, São Paulo, SP, Brasil.

http://dx.doi.org/10.1590/1806-9282.64.04.374

\begin{abstract}
SUMMARY
OBJECTIVE: To evaluate the incidence, mortality and cost of non-traumatic abdominal emergencies treated in Brazilian emergency departments.

METHODS: This paper used DataSus information from 2008 to 2016 (http://www.tabnet.datasus.gov.br). The number of hospitalizations, costs - AlH length of stay and mortality rates were described in acute appendicitis, acute cholecystitis, acute pancreatitis, acute diverticulitis, gastric and duodenal ulcer, and inflammatory intestinal disease.

RESULTS: The disease that had the highest growth in hospitalization was diverticular bowel disease with an increase of $68.2 \%$. For the period of nine years, there were no significant changes in the average length of hospital stay, with the highest increase in gastric and duodenal ulcer with a growth of $15.9 \%$. The mortality rate of gastric and duodenal ulcer disease increased by $95.63 \%$, which is signifcantly high when compared to the other diseases. All had their costs increased but the one that proportionally had the highest increase in the last nine years was the duodenal and gastric ulcer, with an increase of $85.4 \%$.
\end{abstract}

CONCLUSION: Non-traumatic abdominal emergencies are extremely prevalent. Hence, the importance of having updated and comparative data on the mortality rate, number of hospitalization and cost generated by these diseases to provide better healthcare services in public hospitals.

KEYWORDS: Emergencies. Mortality. Cost and cost analysis. Abdominal pain. Pancreatic diseases. Digestive system diseases. Cholelithiasis. Stomach ulcer

\section{INTRODUCTION}

Historically, in emergency departments, trauma is the most frequent pathological condition (20.1\%), followed by cardiopulmonary disorders $(13.8 \%)$ and gastrointestinal problems, including abdominal pain and digestive symptoms (13.6\%) ${ }^{1}$. Acute abdominal pain is one of the most common causes for referral to the emergency department (9.1\%) and to emergency surgery, in addition to being the most common cause for non-trauma-related hospital admissions ${ }^{1-3}$. Patients that arrives with this symptom as main complaint in the admission is subjected to a series of complemen- tary exams, such as abdominal radiography (30.1\%), abdominal ultrasound (43.9\%), CT scan (16.3\%), blood testing (90.4\%) and urine analysis (18\%), which increase hospital costs. Furthermore, 35\% of these patients with acute abdominal pain are admitted. ${ }^{3}$

There is a high prevalence of abdominal emergencies of non-traumatic origin treated worldwide; however, there are only a few studies on this topic in our community.

This is a national database study with the purpose of assessing the evolution of incidence, mortality and cost of non-traumatic abdominal emergencies treated in Brazilian emergency departments.

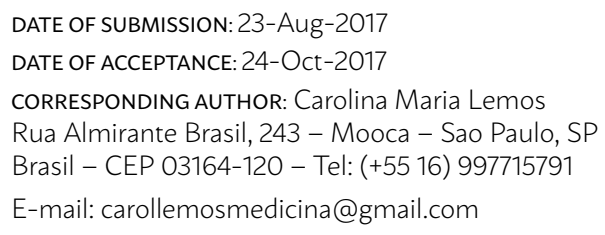

carollemosmedicina@gmail.com marianaalem@outlook.com drtercio@me.com 


\section{METHODS}

This paper used information from DataSUS from 2008 to 2016 (http://www.tabnet.datasus. gov.br/cgi/deftohtm.exe?sih/cnv/niuf.def). In order to obtain the data, it was necessary to access the link of the Hospital Information System (SIH) and insert the CID 10 of the following diseases: acute appendicitis, acute cholecystitis, acute pancreatitis, gastric and duodenal ulcer, inflammatory bowel disease and acute diverticulitis. From there, the following variables were analysed: number of admissions, average of hospital stay, mortality rate and average admission cost (AIH). Each one of these diseases and their variables were assessed between 2008 and 2016.

Data was exposed in Excel spreadsheets, displayed in charts and compared against one another in relation to the diseases and variables assessed. The statistical analysis was carried out through Qui-square, considering $\mathrm{p}<0.05$ as significant.

The research project was submitted for appreciation and approval of the Research Ethics Committee from the Universidade Anhembi Morumbi.

\section{RESULTS}

In descending order, non-traumatic abdominal emergencies with higher incidence treated in Brazilian emergency departments were cholelithiasis and cholecystitis, appendix diseases, acute pancreatitis, gastric and duodenal ulcer, diverticular disease and inflammatory bowel disease.
Analysing the data on Figure 1, it is possible to notice that until 2013, cholelithiasis and cholecystitis led the number of admissions, followed by appendix diseases. However, this relation reversed in the last years, with larger number of appendix diseases. However, the disease with higher growth in number of admissions was the diverticular disease, with an increase of 2,954 cases a year (68.2\%), comparing 2008 with 2016. Appendix diseases and acute pancreatitis had similar percentage increases in this period, 34,630 (45.7\%) and 9,004 (42.8\%), respectively. These three diseases were the ones that had a growth proportionally higher than the Brazilian population in this period, and the diverticular disease had a growth significantly higher than the others $\operatorname{did}(p<0.001)$. Cholelithiasis and cholecystitis had a growth of 11,901 (11.9\%) and inflammatory bowel disease, $160(4 \%)$ in the same period. On the other hand, there was a decrease of $6,700(40 \%)$ in admissions due to gastric and duodenal ulcer.

Over the eight years, there were no major variations in the hospital stay average. The disease with higher increase was the gastric and duodenal ulcer, with a growth of 0.81 day $(15.9 \%)$, followed by inflammatory bowel disease, with an increase of 0.55 day (8.15\%); pancreatitis, with an increase of 0.5 day (7.41\%); cholelithiasis and cholecystitis, with an increase of 0.31 day (7.9\%); diverticular disease, with a decrease of 0.45 day (7\%), and appendix disease, with a decrease of 0.47 day (12\%) (Figure 2).

Among these diseases, mortality rate due

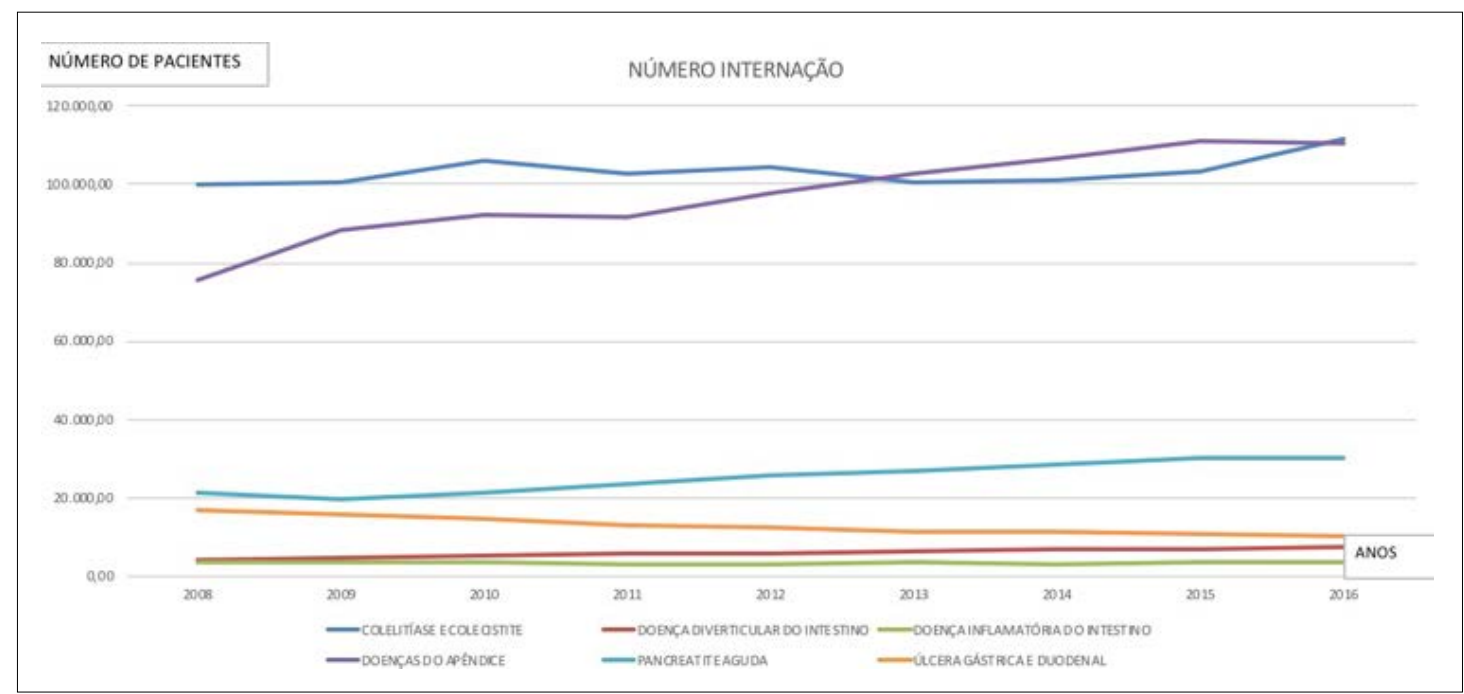

FIGURE 1. Number of admissions per non-traumatic abdominal diseases between 2008 and 2016. 


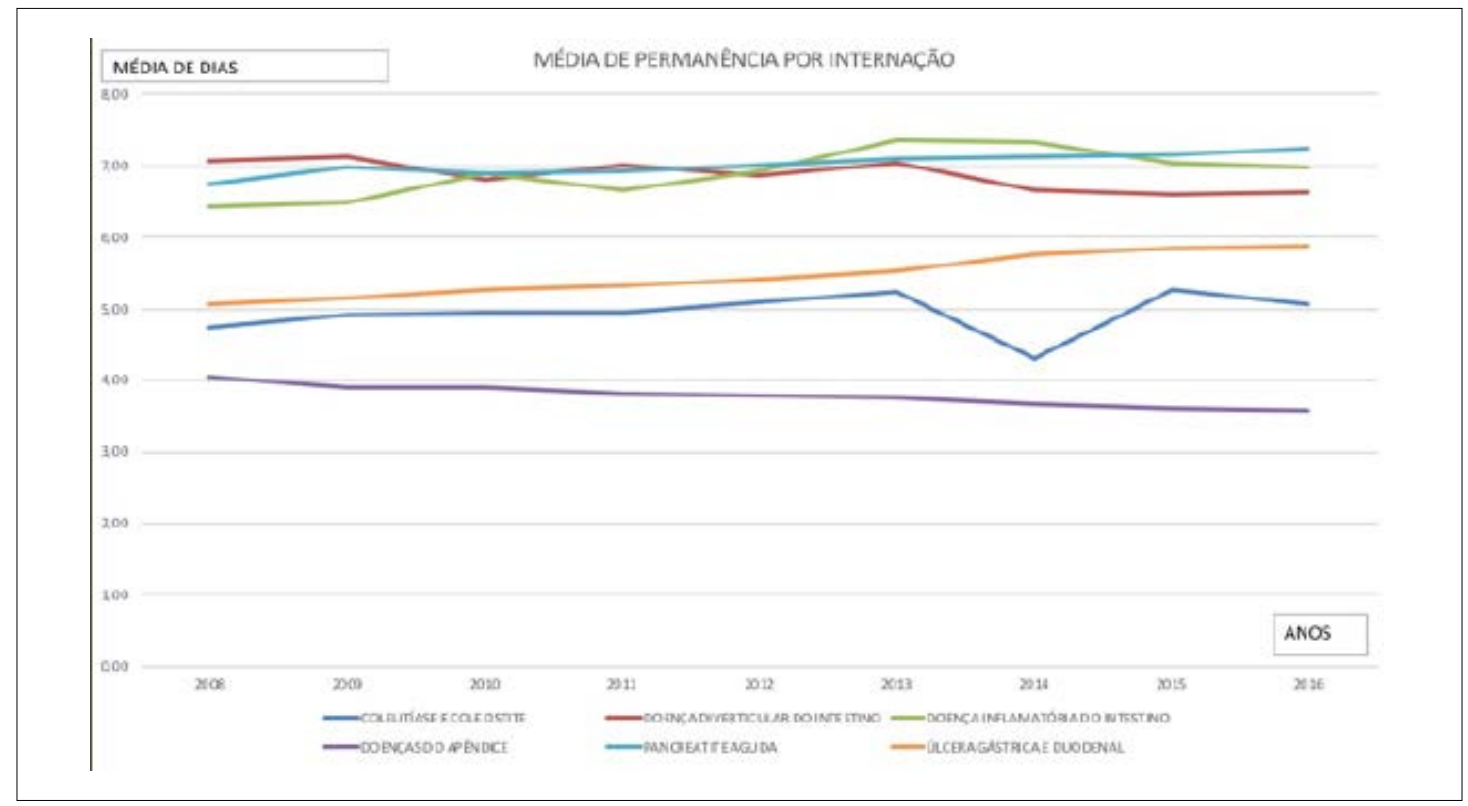

FIGURE 2. Average of hospital stay per non-traumatic abdominal diseases between 2008 and 2016.

to gastric and duodenal ulcer was the only one that presented a significant increase, with 4.6 deaths/1,000 people (95.63\%), when compared to the other diseases: cholelithiasis and cholecystitis, with an increase of $0.16(10.3 \%)$; acute pancreatitis, with an increase of $0.05(0.9 \%)$; acute diverticulitis, with a decrease of 0.37 (4.7\%); inflammatory bowel disease, with a decrease of $0.22(7.4 \%)$ and appendix disease, with a decrease of $0.11(24 \%)$, when comparing 2008 and 2016 (Figure 3).

All diseases assessed had their average admission cost (AIH) increased between 2008 and 2016, and diverticular disease maintained the highest value. However, the one that had the highest proportional increase over the last eight years was gastric and duodenal ulcer, with an increase of BRL 555.4 per admission (85.4\%) $(\mathrm{p}<0.001)$, followed by inflammatory bowel disease, with an increase of BRL 234 per admission (42\%); acute pancreatitis, with an increase of BRL 224.95 per admission (41.1\%); diverticular disease, with an increase of BRL 454 per admission (36.9\%); cholelithiasis and cholecystitis, with an increase of BRL 190 per admission (34.5\%) and lastly, appendicitis, with an increase of BRL 150.86 per admission (30.3\%) (Figure 4).

\section{DISCUSSION}

Abdominal emergencies of non-traumatic origin are extremely prevalent in emergency departments worldwide, with a significant impact on mortality rate, on number of hospital admissions and on costs. This is a national study that correlates the main gastroenterological emergencies of non-traumatic origin with variables assessed.

Diverticulosis is a phenomenon that depends on age, affecting up to $60 \%$ of adults over 60 years old, which justifies it being the disease with the higher growth in number of admissions $(68.2 \%)$, once the elderly population is the one presenting the higher growth projection worldwide ${ }^{4}$. This projection, added to the increase in morbidities (obesity, diabetes mellitus), also makes cholelithiasis, a disease already with large prevalence in the population, lead the number of hospital admissions. ${ }^{5}$

Appendicitis shares the leadership in number of admissions with cholecystitis, since even though it is more prevalent children and young adults, it is the intra-abdominal pathological condition that most requires surgical interventions in the emergency room, resulting in a high number of hospital admissions. ${ }^{2,6}$

The availability of proton-pump inhibitors and their more frequent use, in addition to the H. pylori treatment, have contributed to a reduction of gastric and duodenal ulcer prevalence, and the ulcer cases admitted represent only the severe cases $(10 \%$ of the total peptic ulcer cases), which is related to a lower average of hospital stay. ${ }^{7}$

On the other hand, the mortality rate of gastric and duodenal ulcer had an increase of $95.63 \%$, since it takes into account that admissions represent the complicated ulcer cases that $15 \%$ evolve to a diges- 


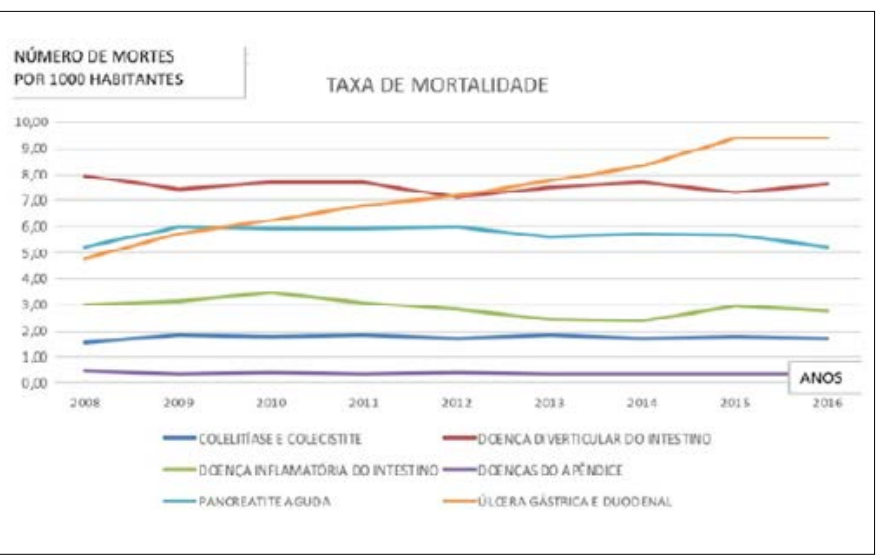

FIGURE 3. Mortality rate per non-traumatic abdominal diseases between 2008 and 2016.

tive bleeding, $7 \%$ to perforation and less than $2 \%$, to obstruction. $^{7}$

Appendix diseases had a decrease of $24 \%$ in the mortality rate, probably due to an early and more appropriate treatment. Furthermore, the use of laparoscopic appendectomy, a minimally invasive method associated with less incidence of post-surgery complications, had a significant growth in past years ${ }^{6}$. According to a study carried out by Santos et al. ${ }^{6}$, the mortality rate was $57.1 \%$ lower in the laparoscopic method when compared to the open appendectomy, a statistically significant difference, however taking into account that this study did not compare the access methods stratified by severity ${ }^{6}$. On the other hand, the literature is clear when stating the advantages of the laparoscopic method such less post-surgery pain, early return to activities and better aesthetic result. ${ }^{8-10}$

The diverticular disease remained with the highest AIH value due to the complexity of its treatment. In studies carried out by the Johns Hopkins University School of Medicine, it was noticed that from 310,983 visits to the emergency department for diverticulitis, $53 \%$ resulted in hospitalization and $6 \%$ in surgical intervention. From those $6 \%, 75 \%$ had a rectosigmoidectomy and $16 \%$ had a left hemicolectomy, justifying the high hospital costs., ${ }^{41}$

In this study, the disease that had the highest proportional cost increase in the period of nine years was the gastric and duodenal ulcer, with an increase of $85.4 \%$ due to the higher severity of the cases and to the need for complex procedures. Taking into account the inflation of $74.79 \%$ in this period, the only disease that had a cost increase above the inflation rate was the gastric and duodenal ulcer. All others

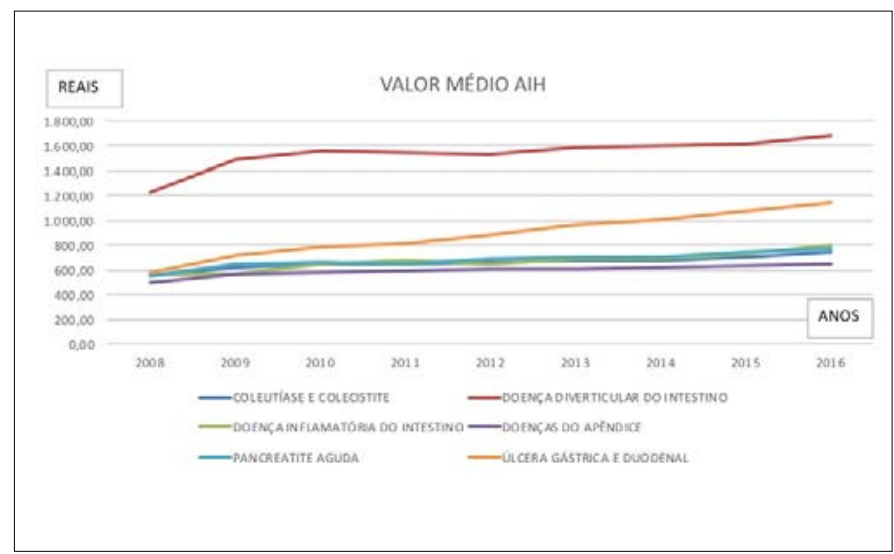

FIGURE 4. Average costs in Brazilian expenses per admission of non-traumatic abdominal diseases between 2008 and 2016.

presented cost reduction when compared to the inflation. This can be explained by the complexity of the presentation forms of the gastric and duodenal ulcer, such as bleedings and perforation.

It is believed that a portion of the population does not have access to ulcer diseases treatment, with difficult access to gastroenterologists, exams such as endoscopy and drug treatment, even though the distribution of proton-pump inhibitors by the government is free. This scenario causes the sick person, in lower number, to present the severe complications of peptic ulcer disease, thus requiring prolonged admissions, blood transfusions, emergency endoscopies and sometimes, surgical procedures, which increases its cost.

Appendix diseases were the ones with lower increase in AIH average value, even with a higher use of the laparoscopic method. ${ }^{6}$

This paper presents limitations since DataSUS information spreadsheets have a limited number of data, preventing analyses that are more complex. However, this study shows the main cases of non-traumatic abdominal emergencies in the Country, with results that can guide healthcare policies and hospital emergencies cost analysis in Brasil.

\section{CONCLUSION}

There was an increase in the number of admissions of all the non-traumatic abdominal diseases, except for the gastroduodenal ulcer. There was a significant increase of mortality by gastroduodenal ulcer. Treatment costs have increased for all non-traumatic abdominal diseases, especially for the gastroduodenal ulcer. 


\section{RESUMO}

OBJETIVO: Avaliar a evolução da incidência, mortalidade e custo das urgências abdominais não traumáticas atendidas nos serviços de emergência do Brasil durante o período de nove anos.

MÉTODOS: Este trabalho utilizou informações do DataSus de 2008 a 2016, (http://www.tabnet.datasus.gov.br). Foram analisados número de internações, valor médio das internações $(A I H)$, valor total das internações, dias de permanência hospitalar e taxa de mortalidade das seguintes doenças: apendicite aguda, colecistite aguda, pancreatite aguda, diverticulite aguda, úlcera gástrica e duodenal, e doença inflamatória intestinal.

RESULTADOS: A doença que teve o maior crescimento do número de internações foi a doença diverticular do intestino, com o valor de $68,2 \%$. Ao longo dos nove anos não houve grandes variações da média de permanência hospitalar, sendo que o maior aumento foi o da úlcera gástrica e duodenal, com crescimento de 15,9\%. A taxa de mortalidade da doença por úlcera gástrica e duodenal teve um aumento de 95,63\%, consideravelmente significante quando comparada com as outras doenças. Todas tiveram seus valores de AlH aumentados, porém, a que proporcionalmente teve o maior aumento nos últimos nove anos foi a úlcera gástrica e duodenal, com um acréscimo de 85,4\%.

CONCLUSÃO: As urgências abdominais de origem não traumática são de extrema prevalência, por isso a importância em ter dados atualizados e comparativos sobre a taxa de mortalidade, o número de internações e os custos gerados por essas doenças, para melhor planejamento dos serviços públicos de saúde.

PALAVRAS-CHAVE: Emergências. Mortalidade. Custos e análise de custo. Dor abdominal. Pancreatopatias. Doenças do sistema digestório. Colelitíase. Úlcera gástrica.

\section{REFERENCES}

1. Viniol A, Keunecke C, Biroga T, Stadje R, Dornieden K, Bösner S. Studies of the symptom abdominal pain: a systematic review and meta-analysis. Fam Pract. 2014;31(5):517-29

2. Lin KB, Chan CL, Yang NP, Lai RK, Liu YH, Zhu SZ. Epidemiology of appendicitis and appendectomy for the low-income population in Taiwan, 2003-2011. BMC Gastroenterol. 2015;15:18.

3. Nardi AM, Caporale E, Morselli-Labate N. Acute abdominal pain in the emergency department of a university hospital in Italy. Bolonha: University Hospital Malpighi; 2015. cap. 2.

4. Schneider EB, Singh A, Sung J, Hassid B, Selvarajah S, Fang SH, et al. Emergency department presentation, admission, and surgical intervention for colonic diverticulitis in the United States. Am J Surg. 2015;210(2):404-7.

5. Maya MCA, Freitas RG, Pitombo MB. Colecistite aguda: diagnóstico e tratamento. Rev Hosp Universitário Pedro Ernesto. 2009;8(1):1:2-9.

6. Santos F, Cavasana GF, Campos T. Perfil das apendicetomias realizadas no sistema público de saúde do Brasil. Rev Col Bras Cir. 2017;44(1):4-8.
7. Oliveira AF, Carvalho IR, Costa MFS, Lobato LCP, Silva RS. Estimativa da prevalência e da mortalidade por complicações da úlcera péptica, Brasil, 2008: uma proposta metodológica. Epidemiol Serv Saúde. 2015;24(1):383-94.

8. Gomes CA, Nunes TA. Classificação laparoscópica da apendicite aguda: correlação entre graus da doença e as variáveis perioperatórias. Rev Col Bras Cir. 2006;33(5):289-93.

9. Wei $B$, Qi CL, Chen TF, Zheng ZH, Huang JL, Hu BG, et al. Laparoscopic versus open appendectomy for acute appendicitis: a metaanalysis. Surg Endosc. 2011;25(4):1199-208.

10. Ohtani H, Tamamori $Y$, Arimoto $Y$, Nishiguchi $Y$, Maeda K, Hirakawa K. Meta-analysis of the results of randomized controlled trials that compared laparoscopic and open surgery for acute appendicitis. J Gastrointest Surg. 2012;16(10):1929-39.

11. Gajendran M, Umapathy C, Loganathan P, Hashash JG, Koutroubakis IE, Binion DG. Analysis of hospital-based emergency department visits for inflammatory bowel disease in the USA. Dig Dis Sci. 2016;61(2):389-99 